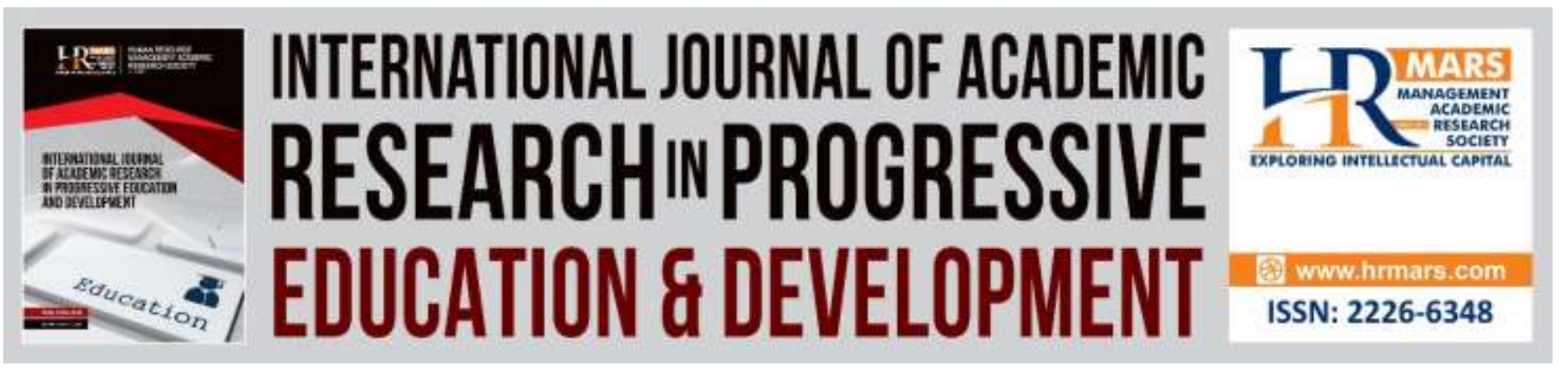

\title{
Are they ready to Become Educators? A Self-Assessment among Bachelor of Education (Sport Sciences \& Physical Education) Undergraduates, Sultan Idris Education University, Malaysia
}

Norhazira Abdul Rahim, Nurul Insana Sabudin, Nor Aijratul Asikin Mohamad Shalan, Julismah Jani, Mohd Izwan Shahril

To Link this Article: http://dx.doi.org/10.6007/IJARPED/v8-i2/5908

DOI: 10.6007/IJARPED/v8-i2/5908

Received: 12 Jan 2019, Revised: 01 Feb 2019, Accepted: 27 Feb 2019

Published Online: 17 March 2019

In-Text Citation: (Rahim, Sabudin, Shalan, Jani, \& Shahril, 2019)

To Cite this Article: Rahim, N. A., Sabudin, N. I., Shalan, N. A. A. M., Jani, J., \& Shahril, M. I. (2019). Are they ready to Become Educators? A Self-Assessment among Bachelor of Education (sport Sciences \& Physical Education) Undergraduates, Sultan Idris Education University, Malaysia. International Journal of Academic Research in Progressive Education and Development, 8(2), 329-337.

Copyright: (c) 2019 The Author(s)

Published by Human Resource Management Academic Research Society (www.hrmars.com)

This article is published under the Creative Commons Attribution (CC BY 4.0) license. Anyone may reproduce, distribute, translate and create derivative works of this article (for both commercial and non-commercial purposes), subject to full attribution to the original publication and authors. The full terms of this license may be seen

at: http://creativecommons.org/licences/by/4.0/legalcode

Vol. 8(2) 2019, Pg. 329 - 337

http://hrmars.com/index.php/pages/detail/IJARPED

JOURNAL HOMEPAGE

Full Terms \& Conditions of access and use can be found at http://hrmars.com/index.php/pages/detail/publication-ethics 


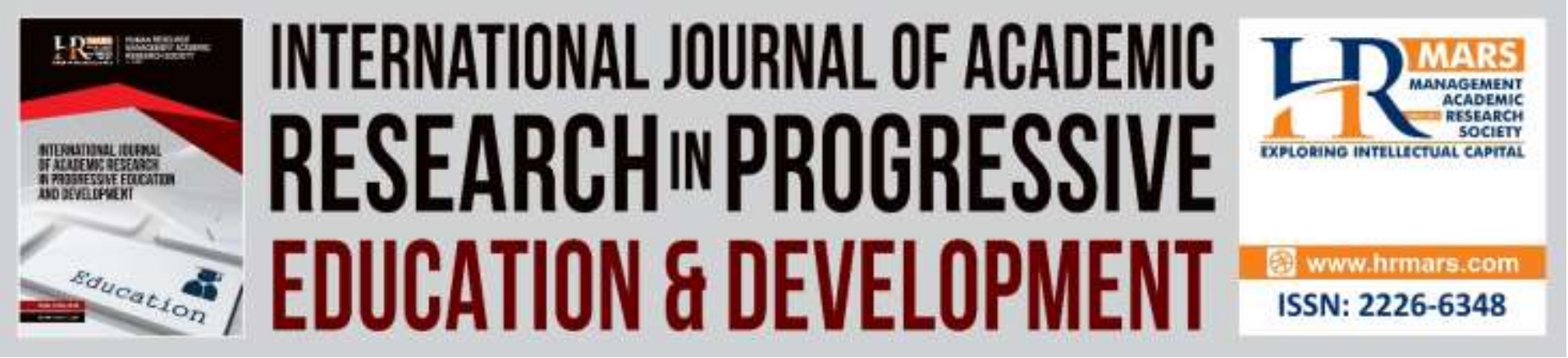

\title{
Are they ready to Become Educators? A Self- Assessment among Bachelor of Education (Sport Sciences \& Physical Education) Undergraduates, Sultan Idris Education University, Malaysia
}

\author{
Norhazira Abdul Rahim, Nurul Insana Sabudin, Nor Aijratul Asikin \\ Mohamad Shalan, Julismah Jani, Mohd Izwan Shahril \\ Faculty of Sport Science and Coaching, Sultan Idris Education University, 35900, Tanjong Malim, \\ Perak, Malaysia
}

\begin{abstract}
A good quality of educator is probably the most critical part of learning process. Considering this, the fresh graduates' teacher must possess the competency in various areas to prepare with the challenges of the $21^{\text {st }}$ century. The aim of this study is to determine the readiness level of Bachelor of Education (B. Ed) final year undergraduates to become educators. The self-assessment survey was designed in accordance with the Malaysian Teachers' Standards, which explore the knowledge and skills on program learning outcome (PLO), moral values, information \& communication technology (ICTs), language, soft skills, teaching \& facilitation and assessment \& evaluation (A\&E). The respondents were the final year undergraduates in Sultan Idris Education University (UPSI), Malaysia in academic year of 2018. Results indicated that the final year undergraduates were 'ready' to become educators for 6 out 8 attributes, whereas they were still 'approaching readiness' for Language Skills and A\&E. This may suggested that the final year undergraduates have a higher readiness level for most of the basic knowledge and skills as educators. However to become a competence educator, they need to have a strong knowledge and skills on both language and A\&E skills as they are essential elements in the learning process.
\end{abstract}

Keywords: Readiness, Educators, Self-Assessment, Undergraduates

Introduction

A quality teacher produces a quality student. A teacher or educator who is good in teaching has been recognized as the most critical part of a solid education (Roth \& Swail, 2000). To become a good educator today, the employers are concerned about finding a high quality educator or teacher who are not only have excellent academic background or having basic skill such as reading, writing and listening, but also must be highly capable in higher thinking skills, social skills, creative and innovative. Besides, the good personal qualities such as responsibility, cooperative, selfmotivated and have integrity are playing important key elements of a good educator. The job 
readiness skills or also known as employability skills which include areas of managing sources, communication and interpersonal skills, team work and problem solving (Zinser, 2003) plays an important roles among beginner teachers in school. Readiness is defined as a combination of one's ability and willingness to do a job that indicates a situational need for differing leadership approaches to get that job (Baker, 2002). In the field of education, teachers are more likely to engage in the tasks and perform in a successful way when they feel confident and competent (Bandura, 1995). In this study, in order to obtain a better understand judgment of 'readiness to teach' among the final year undergraduates of B. Ed programme, we have conducted a selfevaluation among them which the questions were developed based on the Malaysian Teachers' Standard.

\section{Literature Review}

It has been widely recognized that the teachers' quality influence student achievement and success in school. The critical importance of teaching in the delivery of quality education is acknowledged by educators, practitioners, ministers of education, teacher unions and society at large (Coolahan, 2003). Additionally, new teachers which joining the teaching profession are from different levels of knowledge, skills and understandings regarding content and pedagogy. In Malaysia, the policy of Ministry of Education's (MoE) is to elevate the teaching profession by increasing the quality of teachers, advancing teaching as a career and improving the welfare of teachers. Thus, the MoE of Malaysia has developed The Malaysian Teachers' Standard (MTS) as a guide and reference to establish high competency teachers and educators. The three major division standards of the MTS are as follows; Standard 1: The practice and the values of the teaching profession, Standard 2: Knowledge and Understanding and Standard 3: Teaching and Learning Skills (Kementerian Pendidikan Malaysia 2009). Based on some views expressed by stakeholders interviewed in Malaysia, it can be summarized that a good teacher must be possessed pedagogical knowledge, has sound knowledge of the subject matter, passionate about teaching, has flexible attitude and embraces new knowledge and creative with not depending on exam-oriented evaluation (Bourgonje \& Tromp, 2011).

Concerning to the issue, a new National Education Blueprint was developed to raise the education standards to ensure the students are equipped with the $21^{\text {st }}$ century skills. The strategy includes focusing on teaching and learning quality, access to reliable and meaningful information, transparent accountabilities and appropriate learning environments and infrastructure (Kementerian Pendidikan Malaysia 2012). Even though the use of technology has been thought may scale up the quality of teaching and learning, regardless it will only becomes important when the teachers use it in proper way or optimum in teaching and learning process. Previously, it has been revealed that although there are some who claim the presence of technology in the classroom creates pressure and requires effective use (Kozma \& Voogt, 2003), in spite of this fact it related to teacher's attitudes and level of knowledge (Paraskeva, et al. 2008).

The development of education on global scale has been greatly contributed by the using of web-base learning system (Gebre, Saroyan \& Bracewell, 2014; Zainuddin, 2015), however it is still has some limitations, such as students' physical interaction and teachers' assessment toward students' body languange (Pannan \& Legge, 2016). Teachers also need to show their creativity and provide an innovative approach in order to enhance students' understanding. At present, blended learning has been widely implemented which combine the conventional class (face-to-face 
INTERNATIONAL JOURNAL OF ACADEMIC RESEARCH IN PROGRESSIVE EDUCATION AND DEVELOPMENT

Vol. 8, No. 2, 2019, E-ISSN: 2226-6348 @ 2019 HRMARS

approaches) and technology-based learning environments (online approaches). A current study reported by Jani, et al., (2018) suggests the effectiveness of blended learning as an innovative approach on the strategies and tactics awareness in solving game problems and making decisions based on the Teaching Games for Understanding method.

\section{Objective}

This study aims to determine the readiness level of Bachelor of Education (Sport Science and Physical Education) final year undergraduates, Faculty of Sport Science \& Coaching, UPSI to become educators in school.

\section{Methodology}

The respondents were undergraduates from Faculty of Sport Sciences and Coaching, Sultan Idris Education University (UPSI), Perak, Malaysia. All participants were at their final semester of study (8 semesters); aged 22-29 years old. Of the 97 undergraduates who responded to the questionnaire, $56 \%$ were females and $41 \%$ were males from two academic program, which are Bachelor of Education; B Ed (Physical Education) (60.8\%) and B Ed (Sport Sciences) (39.2\%). The demographic characteristics of the participants are included in Table 1.

This research design is divided into two stages. The first stage of this study is the development of self-assessment questionnaire (SAQ) followed by the validation by the experts. The second stage consists of the distribution of the SAQ to the identified respondents, which followed by data collection and data analysis. The questionnaire were distributed in the class and been collected back within the same session. The purpose of the questionnaire and how they should be answered was explained before answering.

\section{Self-Assessment Questionnaire (SAQ) Development and Validation}

The Self-Assessment Questionnaire (SAQ) were constructed based on a previous survey by Jani et al. 2016. It was modified and newly designed based on the attributes of The Malaysian Teachers' Standard (MTS) published by Ministry of Higher Education (MoE) as a guide and reference. Items were generated in two stages. First, a preliminary pool of 68 items was developed which comprised of six parts; demographics characteristics, courses mastery, knowledge applied, basic skills gained, teaching \& facilitation skills gained and future education planning. Secondly, a comprehensive, relevance and clarity of these items were accessed by an expert panel composed of 3 field professionals who actively involved in Secondary and Higher Education. Based on their feedback and response, the questionnaire items were modified into 36 closed-ended questions by combining and adding additional items, and also excluding irrelevant items.

The SAQ was comprised into four sections, Section A : Demographic characteristics, Section B: Knowledge and Skills based on Programme Learning Outcomes, Co-curricular and Moral Values. Section C: Other Basic Skills and Section D: Learning and Facilitation Skills. Table 2 shows the Undergraduates' Knowledge and Skills Readiness Scale, which mean score ranging from 4.00 to 5.00 is interpreted as 'Ready'; 3.00 to 3.99 is interpreted as they are 'Approaching Readiness', whereas a mean score below 3.00 is referring to 'Developing Readiness' (Tan, Kiran \& Diljit, 2017). 
Table 1

Demographic characteristics of participants

\begin{tabular}{|c|c|c|}
\hline Demographic characteristics & Frequency & $\%$ \\
\hline \multicolumn{3}{|l|}{ Academic Programme } \\
\hline B. Ed (Physical Education) & 59 & 60.8 \\
\hline B. Ed (Sport Sciences) & 38 & 39.2 \\
\hline \multicolumn{3}{|l|}{ Gender } \\
\hline Male & 41 & 42.3 \\
\hline Female & 56 & 57.7 \\
\hline \multicolumn{3}{|l|}{ Age } \\
\hline $22-29$ years & 97 & 100 \\
\hline \multicolumn{3}{|l|}{ Race } \\
\hline Malay & 83 & 85.6 \\
\hline Chinese & 2 & 2.1 \\
\hline Others & 12 & 12.4 \\
\hline \multicolumn{3}{|l|}{ Highest Academic Qualification } \\
\hline Malaysia Highest School Certificate (STPM) & 78 & 80.4 \\
\hline Matriculation & 17 & 17.5 \\
\hline Diploma & 2 & 2.1 \\
\hline \multicolumn{3}{|l|}{ Current Level of Cumulative Grade Point Average (CGPA) } \\
\hline \multicolumn{3}{|l|}{ First Class } \\
\hline Second Class Upper & 26 & 26.8 \\
\hline \multirow[t]{2}{*}{ Second Class Lower } & 56 & 57.7 \\
\hline & 15 & 15.5 \\
\hline
\end{tabular}

Table 2

The Undergraduates' Knowledge and Skills Readiness Scale

\begin{tabular}{l|c|c}
\hline \multicolumn{2}{c|}{ Likert Scale/ Mean Score } & Readiness Level \\
\cline { 1 - 2 } Strongly agree & 5.00 & Ready \\
\hline Agree & $4.00-4.99$ & Approaching Readiness \\
\hline Neutral & $3.00-3.99$ & \\
\hline Disagree & $2.00-2.99$ & \multirow{2}{*}{ Developing Readiness } \\
\hline Strongly Disagree & $1.00-1.99$ & \\
\hline
\end{tabular}

\section{Data Analysis}

Data were statistically analyzed using SPSS ${ }^{\circledR}$ version 22.0. The frequencies and percentages were used for descriptive statistics.

\section{Results}

Table 3 shows the validity score of SAQ obtained from experts, which overall score of validity is $r=$ .96. The content of SAQ include the skills and knowledge based on Program Learning Outcomes (PLO) for each academic program as listed in Table 4 and the list of attributes of knowledge and skills as shown by Table 5. 
INTERNATIONAL JOURNAL OF ACADEMIC RESEARCH IN PROGRESSIVE EDUCATION AND DEVELOPMENT

Vol. 8, No. 2, 2019, E-ISSN: 2226-6348 C 2019 HRMARS

Table 3

The validity score for Self-Assessment Questionnaire items

\begin{tabular}{|c|c|}
\hline Item assessed & $\begin{array}{c}\text { Validity Score } \\
\text { (mean) }\end{array}$ \\
\hline Knowledge \& Skills based on Programme Learning Outcomes (PLO) & \\
B Ed (Physical Education) & 0.94 \\
B Ed (Sport Sciences) & 0.92 \\
\hline & \\
\hline Other Basic Skills & 0.92 \\
Based on co-curricular activities & 0.97 \\
Information \& communication technology & 0.97 \\
Language & 0.97 \\
Soft skills & 0.97 \\
Moral values & 0.98 \\
\hline Learning and Facilitation Skills & 0.98 \\
Field content & 0.97 \\
Learning \& Facilitation & \\
Assessment \& Evaluation & 0.96 \\
\hline Overall Mean & 0.96 \\
\hline
\end{tabular}

The undergraduates' readiness is measured by the mean score of each construct as in Table 6 . The highest mean score of undergraduates' readiness is moral value readiness with mean score of 4.48 ( $\mathrm{sd}=0.41$ ) followed by knowledge and skills based on co-curricular activities (mean score $4.22, \mathrm{sd}=0.47)$. The highest mean score in moral value indicates that they are 'ready' in their intrapersonal perspectives which reflected by the moral values.

The other indicators that show they are 'ready' are knowledge and skills based on PLO (B. Ed Physical Education; 4.12, sd=0.46 \& B. Ed Sport Science; 4.07, sd=0.48), followed by ICT skills (4.03, sd=0.84), soft skills $(4.14, \mathrm{sd}=0.50)$, field content $(4.2, \mathrm{sd}=0.62)$ and teaching and facilitation (T\&F) $(4.09, \mathrm{sd}=0.54)$. The lowest mean scores are shown by two indicators which are language skills (3.44, sd=0.58) and assessment and evaluation skills (A\&E) (3.96, sd=0.62), which indicates that they are 'approaching readiness' in these two aspects. 
INTERNATIONAL JOURNAL OF ACADEMIC RESEARCH IN PROGRESSIVE EDUCATION AND DEVELOPMENT

Vol. 8, No. 2, 2019, E-ISSN: 2226-6348 @ 2019 HRMARS

Table 4

The list of Programme Learning Outcomes for each academic programme.

\begin{tabular}{|c|c|}
\hline Academic Programme & Programme Learning Outcomes (PLO) \\
\hline $\begin{array}{l}\text { B. Ed (Physical Education) } \\
n=38\end{array}$ & $\begin{array}{l}\text { Mastery knowledge and pedagogical in Physical \& Health Education field } \\
\text { Mastery technical skills and able to teach Health \& Physical Education subject } \\
\text { Apply information and education technology } \\
\text { Practice professionalism, values, attitudes and ethical } \\
\text { Demonstrate social responsibilities } \\
\text { Managing information effectively and has lifelong learning capabilities } \\
\text { Think creatively and critically } \\
\text { Able to conduct research } \\
\text { Responsive to current issues in Physical and Health Education }\end{array}$ \\
\hline $\begin{array}{l}\text { B. Ed (Sport Sciences) } \\
n=59\end{array}$ & $\begin{array}{l}\text { Mastery knowledge in Sport Sciences field } \\
\text { Mastery practical and technical skills includes communication and information } \\
\text { technology } \\
\text { Carry out social accountability } \\
\text { Practice professionalism, values, attitudes and ethical } \\
\text { Communicate effectively, demonstrate leadership and teamwork skills } \\
\text { Demonstrate problem solving and scientific skills } \\
\text { Show managing skill and practicing entrepreneurial culture }\end{array}$ \\
\hline
\end{tabular}

\section{Discussion}

Graduates need to be equipped with the necessary skills for employment in the school and enable them to smoothly transition from the education environment to the workplace. As beginner in teacher's profession, graduates must improve their intrapersonal value to become more proactive and independent to work as individuals within time constrains and work pressure. In relation to the research question, "Are they ready to become educators?" the results from this study revealed that the undergraduates' are "ready" in most of the indicators on knowledge and skills, except for Language Skills and A\&E skills, which show they are still "approaching readiness". This finding indicates the final year undergraduates have higher readiness levels of the knowledge and understandings in their major discipline chosen, education studies and co-curriculum that educator should possess. However, in term of their Language Skills and A\&E skills, they may need some improvement to achieve mastery on these two essential skills. 


\section{INTERNATIONAL JOURNAL OF ACADEMIC RESEARCH IN PROGRESSIVE EDUCATION AND DEVELOPMENT \\ Vol. 8, No. 2, 2019, E-ISSN: 2226-6348 @ 2019 HRMARS}

\section{Table 5}

The list of attributes of knowledge and skills

\begin{tabular}{|c|c|}
\hline Construct & Indicators \\
\hline Based on co-curricular activities & $\begin{array}{l}\text { Plan and manage the co-curricular/sports activities in school } \\
\text { Organize co-curricular/sports event in school } \\
\text { Become sport competition officer in school } \\
\text { Manage and handle the school's sport facilities and equipment } \\
\text { Assess and evaluate students in sports activities } \\
\text { Apply the moral value among students during handling the co-curricular/sport }\end{array}$ \\
\hline Moral values & $\begin{array}{l}\text { High responsibility } \\
\text { Good time management } \\
\text { Cooperative } \\
\text { Competitive } \\
\text { Independent }\end{array}$ \\
\hline $\begin{array}{l}\text { Information \& Communication Technology } \\
\text { Skills (ICTs) }\end{array}$ & $\begin{array}{l}\text { Microsoft Word skill } \\
\text { Microsoft Excel skill } \\
\text { Microsoft Power Point skill } \\
\text { Other related software skill(s) } \\
\text { Integrate the ICT component into teaching and learning activities }\end{array}$ \\
\hline Language Skills & $\begin{array}{l}\text { Malay communication skill } \\
\text { English communication skill } \\
\text { Other foreign language(s) communication skill } \\
\text { Malay writing skill } \\
\text { English writing skill } \\
\text { Other foreign language(s) writing skill }\end{array}$ \\
\hline Soft skills & $\begin{array}{l}\text { Interpersonal communication skill } \\
\text { Critical and creative thinking skills } \\
\text { Problem solving skill } \\
\text { Analytical and analyzing skills } \\
\text { Teamwork skill } \\
\text { Higher thinking order skill }\end{array}$ \\
\hline Field content & $\begin{array}{l}\text { Design the teaching and facilitation (T\&F) process based on Malaysian Secondary Standard } \\
\text { Curriculum (KSSM) } \\
\text { Prepare the Daily Teaching Plan } \\
\text { Plan the strategy of T\&F based on } 21^{\text {st }} \text { century learning } \\
\text { Plan the strategy of T\&F based on the Curriculum Cross Element }\end{array}$ \\
\hline Teaching and Facilitation (T\&F) & $\begin{array}{l}\text { Use various types of method in T\&F } \\
\text { Flexible in implementing the T\&F method } \\
\text { Use diverse and interesting reference sources in T\&F process } \\
\text { Mastery the various of teaching aids } \\
\text { Assist T\&F process with ICT facilities }\end{array}$ \\
\hline Assessment \& Evaluation (A\&E) & $\begin{array}{l}\text { Implement the A\&E in class } \\
\text { Mastery the various method of A\&E } \\
\text { Continuously implement A\&E } \\
\text { Develop the procedure/ instrument of A\&E } \\
\text { Use the information from A\&E to access T\&F effectiveness }\end{array}$ \\
\hline
\end{tabular}


INTERNATIONAL JOURNAL OF ACADEMIC RESEARCH IN PROGRESSIVE EDUCATION AND DEVELOPMENT

Vol. 8, No. 2, 2019, E-ISSN: $2226-6348$ @ 2019 HRMARS

Table 6

The undergraduates' readiness on knowledge and skills.

\begin{tabular}{l|ccc}
\hline Construct & Mean scores & SD & Readiness Level \\
\hline $\begin{array}{l}\text { Based on PLO } \\
\text { B. Ed (Physical Education) }\end{array}$ & 4.12 & 0.46 & Ready \\
\hline $\begin{array}{l}\text { Based on PLO } \\
\text { B. Ed (Sport Sciences) }\end{array}$ & 4.07 & 0.48 & Ready \\
\hline Based on co-curricular activities & & & Ready \\
\hline Moral values & 4.22 & 0.47 & Ready \\
\hline $\begin{array}{l}\text { Information \& Communication Technology } \\
\text { Skills (ICTs) }\end{array}$ & 4.48 & 0.41 & Ready \\
\hline Language Skills & 4.03 & 0.84 & Rpproaching readiness \\
\hline Soft skills & 3.44 & 0.58 & Ready \\
\hline Field content & 4.14 & 0.50 & Ready \\
\hline Teaching and Facilitation (T\&F) & 4.2 & 0.62 & Ready \\
\hline Assessment \& Evaluation (A\&E) & 4.09 & 0.54 & Approaching readiness \\
\hline
\end{tabular}

The highest score on readiness scale were Moral Values followed by based on Co-Curricular Activities. Thus, this is in line with the core of education, which concerned about the moral values of a teacher. In many situations in schools, teachers require high responsibilities and become independent in certain issues with consideration. A study by Bauml (2009) on pre-service teachers' beliefs about teaching concludes that teachers who get to know their students personally are better to choose appropriate pedagogical methods for instruction and can relate material to students' interest. Effective teachers are always become students' favorite for new and exciting teaching strategies that will keep the students motivated and engaged in the subject taught. The positive results in this study on "Moral Value" which include 'cooperative' indicator, indicates that the graduates have the ability to work with others and may accept different point of view from students or colleagues.

The second highest readiness scale was goes to "Knowledge \& Skills based on Co-Curricular Activities (mean score: 4.22). In Malaysia, students have to take part in three co-curricular activities from three different categories such as uniform unit, club or society as well as sports and games. Teachers will be assigned as advisor to in charge of these activities such as planning, monitoring and evaluating students. Looking at the amount of the workload between teaching and carry out co-curricular programme, it is very important for a teacher to have knowledge and skills on how to plan, manage and organize sports or co-curricular activities. "Teaching \& Facilitation"; T\&F (mean score; 4.08) which appears as "ready" were markedly represent that undergraduates were confident to conduct a class with various method of T\&F with the use of ICT facilities. The teaching method must not only limit to text book or notes only. Integrating technology into classroom is a great way to empower students to stay connected in this technological era. It has been suggested that students are more actively interact and being more engage in classrooms where technology is used effectively (Singh \& Mohamed, 2012).

Apart from T\&F method, infusing soft skills in the class is one of the important parts in education process. Teaching is a complex act, requiring a wide range of knowledge and skills 
including hard and soft skills to successfully manage the demands of the classroom (Ngang, Hashim \& Yunus, 2015). Soft skills complement hard skills which are the technical requirement of the profession especially profession which deal with people face to face (Pachauri \& Yadav 2014). In

"Soft Skills" indicator, the teamwork skills and critical thinking are also a crucial factor determining the undergraduates' competence as beginner teacher (Pop \& Khampirat, 2019). In this study, it appeared that undergraduates are "ready" in term of soft skills which may suggested that they have the fundamental skills that always been preferred by the school or employers. The soft skills aspects among students are an important element to produce graduates which are competitive, efficient and flexible when dealing with real work situation (Anuar \& Esa, 2010). Study by Ngang, Yunus \& Hashim (2015) recommended that teacher educators should utilize the integrated soft skills training module during teaching professional training, as they found that soft skills perceived as important and relevant to the teaching process. Perceived readiness does not exactly mean that a teacher's perceived readiness denotes that $s /$ he is ready in reality; however, teacher's feeling of being ready is important to their ability to execute a behavior (Giallo \& Little, 2003). Previous study revealed that there is a significant relationship between the pre-service teachers' classroom management efficacy and their readiness to manage the challenging classroom behaviors (İnceçay \& Dollar, 2012).

Since the level of readiness of undergraduates on Language Skill and A \& E skills are at "approaching readiness', this may indicate that they are lack of confident on writing and speaking aspects. The weakness in speaking or writing may affect the values of the effectiveness of teaching and learning process. In Malaysia, although the National Schools, in which the Malay language is used as medium of instruction, but it is a must for all educators to be proficient in English to enhance their capabilities in teaching profession with current challenges in the world of education. Same goes to the knowledge and skills on how to assess and evaluate the students' performance in class. Assessment is a critical piece of the learning process, which reflects whether the course's learning objectives have been met. On the other hands, accurate and effective A\&E skills may also motivate students in their academic performance. Instead of that, the students' perception about assessment significantly influences their approaches in learning and studying in class (Struyven, Dochy \& Janssens, 2005).

\section{Conclusion}

Overall, this study found that the final year undergraduates were 'ready' to become educator after finishing their academic program of Bachelor of Education in (Sport Science and Physical Education) in UPSI. This indicate they are ready to become a quality educator who has a positive effect on the student learning process through a combination of content mastery, a broad set of teaching and facilitation skills and interpersonal skills.

However, they were still at the level of 'approaching readiness for Language skills and Assessment \& Evaluation skills. These two attributes play an important role in the teaching processes especially for Assessment \& Evaluation skills which reflected what are the students have been learned and to determine their level of understanding of the particular subject. The factors impacting the readiness level regarding the Language skills and Assessment \& Evaluation skills may include the previous teaching and learning activities which include interaction or communication skills, the content of course offered in their program and their prior teaching experience during practical training. 
INTERNATIONAL JOURNAL OF ACADEMIC RESEARCH IN PROGRESSIVE EDUCATION AND DEVELOPMENT

Vol. 8, No. 2, 2019, E-ISSN: 2226-6348 @ 2019 HRMARS

Altogether, it may suggested that undergraduates must possess and mastery all the essential skills in order to enhance their readiness to become a good quality of educator. Take into consideration, the institutional are suggested to plan and revise the teaching and learning process or the curriculum elements in order to improve the essential skills of undergraduates. Besides, the student itself needs to have a strong determination and highly motivated to become a high quality of educator.

\section{Acknowledgement}

This research was part of research funded by Sultan Idris Education University (UPSI) Research Grant (Project Code: 2017-0321-107-01)

\section{Corresponding Author}

Name : Norhazira Abdul Rahim (Ph.D)

Address : Faculty of Sport Science and Coaching, Sultan Idris Education University, 35900, Tanjong Malim, Perak, Malaysia

\section{References}

Anuar, A. A., \& Esa, A. (2010). Penerapan Kemahiran Insaniah di Pusat Giat MARA (PGM): Satu Analisis Perbandingan" dalam A. Esa \& MZ Mustafa [eds]. Kemahiran Insaniah: Kajian di Institusi-institusi Pengajian. Batu Pahat, Johor. Penerbit Universiti Tun Hussein Onn Malaysia, p. 1-19.

Baker, P. H. (2002), The role of self-efficacy in teacher readiness for differentiating discipline in classroom settings, p.46. Unpublished dissertation.

Bauml, M. (2009). Examining the unexpected sophistication of preservice teachers' beliefs about the relational dimensions of teaching. Teaching and Teacher Education, 25(6), 902e908

Bandura, A. (1995). Perceived self-efficacy in cognitive development and functioning. Educational Psychologist. 28(2), 117-148.

Bourgonje, P., \& Tromp, R. (2011). Quality educators: An international study of teacher competences and standards. Oxfam Novib Educational International.

Coolahan, J. (2003). Attracting, Developing and Retaining Effective Teachers: Country Background report for Ireland. Dublin: Stationery Office.

Giallo, R. \& Little, E. (2003). Classroom behavior problems: The relationship between preparedness, classroom experiences and self efficacy in graduate and student teachers. Australian Journal of Educational and Developmental Psychology,3, 21- 34.

Gebre, E., Saroyan, A., \& Bracewell, R. (2014). Students' engagement in technology rich classrooms and its relationship to professors' conceptions of effective teaching. British Journal of Educational Technology, 45(1), 83-89.

Inceçay, G., \& Dollar, Y. K. (2012). Classroom management, self-efficacy and readiness of Turkish pre-service English teachers. ELT Research Journal, 1(3), 189-198.

Jani, J., Shariff, A. R. M., Salimin, N., Shahril, M. I., Rasyid, N. M., Jusoh, N., Lee, J. L. F., Elumalai, G., Mohamad, N. I. \& Madon, M. S. (2016). Evaluation on the implementation of Bachelor Education Programme, Faculty of Sport Science and Coaching. Journal of Sport Science and Physical Education, Malaysia, 5(1), 77-94.

Jani, J., Muszali, R., Nathan, S., \& Abdullah, M. S. (2018). Blended Learning Approach Using Frog VLE Platform Towards Students' Achievement in Teaching Games for 
INTERNATIONAL JOURNAL OF ACADEMIC RESEARCH IN PROGRESSIVE EDUCATION AND

DEVELOPMENT

Vol. 8, No. 2, 2019, E-ISSN: $2226-6348$ @ 2019 HRMARS

Understanding. Journal of Fundamental and Applied Sciences, 10, 1130-1141.

Kementerian Pendidikan Malaysia (2012). Preliminary Malaysia Education Blueprint 2013-2025. Available from http://www.moe.gov.my/userfiles/file/PPP/Preliminary-Blueprint-Eng.pdf.

Kementerian Pendidikan Malaysia (2009). Standard Guru Malaysia. Malaysia: Dewan Bahasa dan Pustaka.

Kozma, R. B., \& Voogt, J. (2003). Technology, innovation, and educational change: a global perspective: a report of the Second Information Technology in Education Study, Module 2. ISTE (Interntl Soc Tech Educ).

Ngang, T. K., Hashim, N. H., \& Yunus, H. M. (2015). Novice Teacher Perceptions of the Soft Skills Needed in Today's Workplace. Procedia-Social and Behavioral Sciences, 177, 284-288.

Ngang, T. K., Yunus, H. M., \& Hashim, N. H. (2015). Soft skills integration in teaching professional training: Novice teachers' perspectives. Procedia-social and behavioral sciences, 186, 835840.

Pachauri, D., \& Yadav, A. (2014). Importance of soft skills in teacher education programme. International Journal of Educational Research and Technology, 5(1), 22-25.

Pannan, L. J., \& Legge, K. A. (2016). „A Blended Learning Model and a Design Model Combine to Support Academics in Pedagogical Redesign of the Curriculum.".Show Me The Learning. Proceedings ASCILITE, 487-497.

Paraskeva, F., Bouta, H. \& Papagianni, A. (2008). Individual characteristics and computer selfefficacy in secondary education teachers to integrate technology in educational practice. Computers \& Education, 50, 1084-1091.

Pop, C., \& Khampirat, B. (2019). Self-assessment instrument to measure the competencies of Namibian graduates: Testing of validity and reliability. Studies in Educational Evaluation, 60, 130-139.

Roth, D. \& W. S. Swail (2000). Certification and Teacher Preparation in the United States. Washington: Educational Policy Institute

Singht, R. K. T., \& Mohamed, R. A. (2012). Secondary students' perspective on the use of interactive whiteboard for teaching and learning of science in Malaysia. Journal of Education and Practice, 3(7), 9-15.

Struyven, K., Dochy, F., \& Janssens, S. (2005). Students' perceptions about evaluation and assessment in higher education: A review. Assessment \& Evaluation in Higher Education, 30(4), 325-341.

Tan, S. M., Kiran, K., \& Diljit, S. (2017). Examining school librarians' readiness for information literacy education implementation. Malaysian Journal of Library \& Information Science, 20(1).

Zainuddin, Z. (2015). Exploring the potential of Blended Learning and Learning Management System for Higher Education in Aceh. Englisia, 2(2), 70-85. 